\title{
Narrativas de Professoras: teatro e experiência
}

\author{
Andréa Maria Favilla Lobo \\ Universidade Federal do Acre - UFAC
}

\begin{abstract}
RESUMO - Narrativas de Professoras: teatro e experiência Este artigo discute as concepções de e as experiências com o teatro na trajetória de professoras, a partir das análises de seus depoimentos. As categorias analisadas dialogam tanto com os impactos dos processos de socialização dessas docentes em suas escolhas de vida, quanto com as suas concepções sobre o teatro. Tais reflexões são resultado de pesquisa realizada nos anos de 2008 e 2009 em Rio Branco - Acre. Consideraram-se aspectos que permearam as preferências e concepções das docentes, na perspectiva teórica de Pierre Bourdieu, de Bernard Lahire, da História Cultural e da Etnocenologia.

Palavras-chave: Saberes. Experiência. Professor de Teatro. Formação. Etnocenologia.
\end{abstract}

ABSTRACT - Narratives of Teachers: theater and experience - This paper discusses the concepts about and the experiences with the theater in the path of teachers from the analysis of their statements. The categories analyzed dialogue both with the impact of socialization processes of these teachers in their own lives, and its ideas about the theater. Such reflections are the result of research conducted in 2008 and 2009 in Rio Branco - Acre. Considering aspects that permeated the preferences and conceptions of teaching, the theoretical perspective of Pierre Bourdieu, Bernard Lahire, Cultural History and Ethnoscenology.

Keywords: Knowledge. Experience. Acting Teacher. Training. Ethnoscenology.

RÉSUMÉ - Récits des Enseignants: théâtre et experience - Cet article présente les concepts sur et les expériences avec le théâtre 
dans la trajectoire des enseignantes à partir de l'analyse de leurs témoignages. Les catégories analysées dialoguent avec l'impact de leurs processus de socialisation dans leurs choix de vie et avec leurs représentations à propos du théâtre. Ces réflexions sont le résultat des recherches entreprises dans les années 2008 et 2009 à Rio Branco - Acre. On a considerés les aspects qui ont traversées les préférences et les conceptions des enseignentes, du point de vue théorique de Pierre Bourdieu, Bernard Lahire, de l'Histoire culturelle et de l'ethnoscénologie.

Mots-clés: Connaissance. Expérience. Enseignants de Théâtre. Formation. Ethnoscénologie.

\section{Introdução}

Este artigo pretende abordar diferentes concepções e experiências com o teatro a partir da análise dos depoimentos de um grupo de professoras. As análises buscam, em suas múltiplas perspectivas, considerar os efeitos decorrentes sobre essas docentes em relação a suas escolhas de vida, assim como suas opiniões sobre a importância do teatro. Tais reflexões resultam de pesquisa desenvolvida durante os anos de 2008 e 2009 em Rio Branco - Acre.

As entrevistas foram gravadas, em locais escolhidos sempre pelas professoras: praças, escolas, varandas, cafés etc. Foram selecionadas docentes que trabalhavam com teatro como: forma artística principal nas aulas de arte; como atividade extracurricular; ou que trabalhavam as duas formas. O tempo de docência também foi considerado. Cinco professoras possuíam mais de três anos de experiência, enquanto uma possuía menos de três anos de experiência em sala de aula, com o componente curricular arte.

Aqui serão discutidos aspectos que foram considerados relevantes para o entendimento dos processos de formação das professoras que trabalham com o teatro, em salas de aula de escolas estaduais da zona urbana de Rio Branco, Acre. Para isto, foram construídas categorias, a partir da recorrência de elementos considerados significativos, a saber: a figura materna e a escolha profissional; as experiências e concepções sobre o teatro e a produção das preferências. Para garantir o sigilo em relação às identidades das professoras optou-se por utilizar nomes fictícios, assim 
como por não identificar as pessoas e escolas que porventura fossem citadas durante as entrevistas.

Acredita-se que a análise das categorias elaboradas possa trazer contribuições significativas para a discussão em torno dos aspectos formativos dos docentes que trabalham com o teatro, não só nas escolas de Rio Branco, mas também em escolas de outras regiões do país.

\section{A Figura Feminina e a Escolha pela Docência}

Um dos aspectos significativos, em relação ao quantitativo de docentes selecionados para a realização das entrevistas, foi, sem dúvida, o fato de que este é composto integralmente por mulheres. Durante os depoimentos, as justificativas em torno da escolha profissional e vocação para o magistério se concentrou principalmente em torno de dois fatores, a saber: a identificação com a mãe ou professora e a condição social.

Estudos sobre a desvalorização social da profissão docente apontam que essa realidade é antiga e encontramse vestígios de tal fenômeno no mundo grego e romano: receber salário pela realização de um trabalho representava uma condição social inferior. Nesse sentido, o ofício de professor já era desprezado desde então:

A desvalorização social da profissão docente não é um fenômeno propriamente novo. Pelo contrário, o desprezo pelo ofício de professor, como por qualquer outro ofício no qual se ganhava salário, já era explícito no mundo antigo. Afinal, o salário era uma prova de servidão nas sociedades grega e romana, um estigma (Nunes, 1985, p. 59).

No Brasil, na década de 1980, pesquisa realizada na cidade do Rio de Janeiro apontava que, no concurso vestibular, os estudantes de nível socioeconômico mais baixo optavam pelas carreiras de Letras e Pedagogia (Frigotto apud Nunes, 1985).

Ao investigar os fatores que condicionam a escolha da profissão docente, Nunes se afasta da explicação que atribui a opção pelo magistério a uma tendência natural ou vocação. A autora não nega as diferenças individuais, porém chama a atenção para os aspectos que interferem de forma significativa nas escolhas profissionais de 
jovens brasileiros. As relações entre os fatores que interferem em tais escolhas e as próprias escolhas nem sempre estão conscientes para o jovem. Como se percebe no depoimento de Clara:

[...] Eu acho que já era de mim mesma, e como diz o outro, trabalhava sentada sem estar me estressando e na escola a gente tem vários problemas [...] Era de mim mesma ser professora, eu fiz contabilidade, eu fiz três anos de estágio no Banacre, mas não era isso que eu queria [...] eu acho que já era de mim, na verdade era a minha mãe, ela sempre dizia que tinha um sonho [...] Ela nunca estudou, mas se ela soubesse ler ela queria ser bancária ou professora [...] o meu irmão foi ser bancário, eu acabei fazendo as duas coisas, mas aí eu fui ser professora pra fazer a vontade dela [...] acho que foi isso que incentivou também. Ela tem o maior orgulho de ter uma filha professora [...] (Clara) (Grifos meus).

Percebe-se que Clara repete várias vezes a frase "[...] eu acho que era de mim mesma [...]" (Clara), num discurso de convencimento de si sobre uma verdade que ela já havia naturalizado; no entanto, logo depois ela diz: "[...] na verdade era minha mãe [...]" (Clara). Era a tentativa de agradar a mãe e de seguir uma profissão que seria mais condizente ao papel da mulher, já que seu irmão poderia ocupar o lugar que ela havia inicialmente ocupado: "[...] meu irmão foi ser bancário" (Clara). Embora Clara tivesse investido três anos de sua vida numa outra profissão, convenceu-se gradativamente de que estava errada, sendo recompensada por isso pelo reconhecimento de sua mãe: "Ela tem o maior orgulho de ter uma filha professora" (Clara). Pois:

A meu ver, a socialização sofrida pela mulher torna-a extremamente vulnerável à inculcação de valores ou estereótipos pela família, por outros grupos de relação, pelos meios de comunicação de massa e pelo próprio sistema escolar. A mulher recebe influências que a impedem de desenvolver seu potencial no trabalho; interiorizando tais influências passa mesmo a acreditar que há locais melhores para o trabalho feminino, deixando para segundo plano os interesses específicos da profissão (Nunes, 1985, p. 63). 
$\mathrm{O}$ aspecto da discriminação sexual das tarefas, refletido na crescente feminização do magistério, apontado nas discussões de Nunes, pode ser observado no depoimento de Ana. A opção pelo magistério foi construída ao longo de sua identificação com a figura da mãe, que também era professora:

[...] Eu fui aluna dela. Ela era alfabetizadora na época, aí eu fui estudar com ela; eu gostei muito [...] ela me chamava muita atenção. A forma que ela dava aula assim [...] uma pessoa muito carinhosa, muito meiga, atenciosa com os alunos e tudo [...] e mais do que tudo minha mãe, né. Ela dava atenção em dobro pra mim [...] ai eu gostei de estudar com ela $[\ldots]$ (Ana).

Observa-se a mistura de papéis que a mãe desempenhou na vida de Ana. Tal mistura se projeta na concepção que ela vai construir sobre o que é ser professora: "Sabe, enfim, o que o professor faz na sala de aula, é mãe, é pai, é psicólogo, é tudo [...] a gente tem que fazer essa função, aí eu fui gostando assim [...] coração aberto pra área, então eu quero ser [...]" (Ana).

Assim, cabe ressaltar o aspecto que diz respeito aos processos de socialização primária de Ana, isto é, o fato de que é justamente no período da infância que as impressões mais duradouras são construídas, de que é a partir das interações sociais ocorridas no seio das famílias que o indivíduo interioriza o mundo à sua volta, dando sentido a ele, e que compreende os outros como seus semelhantes (Berger; Luckmann, 2005). Tal processo esclarece muitos pontos no que diz respeito à dinâmica social de indivíduos que pertencem ao mesmo grupo familiar. Assim, observa-se no depoimento de Ana que apenas ela decidiu ser professora, apesar de contar com mais sete irmãos. Dessa forma, o investimento afetivo realizado pela mãe, em sua relação com a filha, foi provavelmente o diferencial na escolha de Ana pelo magistério. As configurações sociais presentes na dinâmica social familiar imprimiram interações diferenciadas entre a mãe, o irmão, as irmãs e outros membros do grupo. São relações de interdependência que funcionam de forma heterogênea, o que significa dizer que, apesar de serem irmãos, filhos da mesma mãe, de pertencerem ao mesmo grupo social, as relações de 
interdependência que se estabeleceram no seio dessa família produziram efeitos diferenciados, quanto às escolhas e identificações profissionais em cada sujeito, mesmo que pertençam ao mesmo gênero ou posição social. Nesse sentido, o capital cultural herdado por Ana produziu efeitos em relação a suas preferências profissionais, assim como nas representações sociais que ela construiu sobre ser professora e sobre a escola. Tal capital não foi herdado da mesma forma por seus irmãos e irmãs, embora pertençam ao mesmo grupo familiar. Essa dinâmica é discutida por Bernard Lahire, quando esse autor considera as diferentes condições de herança do capital cultural em famílias de contextos semelhantes. Mesmo no caso de Ana, ou seja, em um único meio familiar, percebe-se que as interações e condições de herança do capital cultural também se deram de forma diferenciada para cada indivíduo, pois:

A presença objetiva de um capital cultural familiar só tem sentido se esse capital cultural for colocado em condições que tornem possível sua "transmissão". Ora, nem sempre isso acontece. As pessoas que têm as disposições culturais susceptíveis de ajudar a criança e, mais amplamente, de socializá-la num sentido harmonioso do ponto de vista escolar nem sempre têm tempo e oportunidade de produzir efeitos de socialização. Nem sempre conseguem construir os dispositivos familiares que possibilitariam "transmitir" alguns de seus conhecimentos ou algumas de suas disposições escolarmente rentáveis, de maneira regular, contínua, sistemática. É por essa razão que, com capital cultural equivalente, dois contextos familiares podem produzir situações escolares muito diferentes na medida em que o rendimento escolar desses capitais culturais depende muito das configurações familiares de conjunto. Podemos dizer, lembrando uma frase célebre, que a herança cultural nem sempre chega a encontrar as condições adequadas para que o herdeiro herde (Lahire, 2008, p. 338).

Nesse sentido, o que Ana reconhece exclusivamente como vocação para o magistério pode ser considerado como a herança de um capital cultural transmitido pela mãe, a partir de configurações familiares que permitiram que ela pudesse herdar o interesse pela profissão e o desejo de ser professora. Nessa perspectiva, infere-se que a associação do exercício da docência com uma vocação, isto é, com um dom, pode ser considerado 
um discurso construído socialmente e naturalizado pelos próprios docentes. No entanto, afirmar que os processos de interiorização da realidade objetiva, na socialização primária de Ana, funcionaram de forma determinista para a constituição de suas escolhas e preferências seria negar outros aspectos que incorrem nos processos de constituição das subjetividades, e que não são exclusivamente definidos na socialização. Esses elementos se configuram como inerentes ao próprio sujeito e aos mecanismos de autoidentificação. Dito de outra forma, são componentes que se inscrevem na capacidade singular de perceber, o próprio corpo, por exemplo, ou se dispor a viver certas experiências de forma diferenciada; vale dizer que:

A biografia subjetiva não é completamente social. O indivíduo apreende-se a si próprio como um ser ao mesmo tempo interior e exterior à sociedade. Isto implica que a simetria entre a realidade objetiva e a subjetiva, nunca é uma situação estática, dada uma vez por todas. Deve ser sempre produzida e reproduzida in actu. Em outras palavras, a relação entre o indivíduo e o mundo social objetivo assemelha-se a um ato continuamente oscilante (Berger; Luckmann, 2005, p. 179).

Percebe-se, no depoimento de outra professora, a dupla função de mãe/professora presente em suas histórias e a influência feminina na opção pelo magistério: Dora atribui força simbólica ao discurso que sela seu destino profissional presente em duas gerações, a mãe alfabetizadora e a promessa feita quando menina para a avó: "[...] culpa da minha avó, [...] por que ela tinha que perguntar o que eu queria ser? Por que, se ela não perguntasse, eu não teria dito, [...] quando ela perguntou e eu disse, os anjos disseram amém [...]" (Dora). Uma metáfora está presente no discurso de Dora, que se vale dos anjos, que escutam a espreita as promessas feitas por uma criança a sua avó, promessas que não poderão ser quebradas, pois possuem como testemunhas o mito do divino. A responsabilidade e o peso de uma opção, que traz também a marca de certo condicionamento social de uma estrutura em que a condição feminina é desenhada com a concordância das outras mulheres da família. $O$ que Dora pergunta 
indiretamente é: poderia haver outras opções de acordo, nesse contrato familiar? Quais as escolhas possíveis para uma menina que se considerava como aluna pouco inteligente? Quando ela diz, "[...] nunca fui uma aluna muito inteligente, a primeira aluna da turma [...]" (Dora), quem mediu essa inteligência e quem disse a ela que ser a primeira aluna da turma era referência de seu nível de inteligência? Tal discurso apresenta caráter despotencializador para Dora, no que tange à visualização de outros caminhos, em que sua capacidade intelectual poderia ser exigida. Sendo assim, a percepção de Dora sobre o seu potencial intelectual abre margem para a problematização das condições do sucesso escolar de determinados alunos e alunas na escola. Ora, em que medida o julgamento de Dora sobre seu próprio status intelectual reflete as dificuldades que porventura vivenciou nos processos de apropriação da educação escolarizada? Tendo em vista que, segundo Bourdieu (1983), a cultura considerada legítima no campo social é reconhecida e ratificada pela escola, infere-se que tal fenômeno social produz, num certo sentido, a exclusão de alunos e alunas que não possuem a devida familiarização com essa cultura de fora da escola. Trata-se, então, mais de uma dificuldade de acesso a esses bens culturais, considerados legítimos, do que propriamente uma incompetência de Dora em lidar com eles.

No que diz respeito à concepção da docência como tarefa divina, a vocação e o dom são entendidos como inatos e, portanto, independentes de uma formação exigida para $\mathrm{o}$ exercício de qualquer atividade profissional. Nessa perspectiva, o dom é concebido como algo que reduz a tarefa do professor, e mesmo a do artista, a determinismos que fogem ao seu controle. Dito de outra forma, deslegitima-se quaisquer iniciativas que visem ao investimento na formação profissional desses sujeitos. No entanto, ao lançar-se outro olhar sobre o dom, pode-se compreendê-lo também como uma metáfora que representa a disponibilidade, a generosidade de um ser em relação ao outro. Nesse sentido, o dom é considerado doação e remete a processos em que tanto o professor quanto o artista se sentiriam implicados em doar aquilo que possuem, favorecendo a outros, as experiências significativas de aprendizagem e a criação 
de novas realidades. O professor seria, então, aquele que se sente comprometido com aquilo que faz e com os impactos de sua ação na sociedade, "[...] o professor aquele que dá o texto a ler, como um dom, [...]" (Larrosa, 2006, p. 140). Dar o texto a ler, como um dom pode ser compreendido, em nosso contexto, como a generosidade da professora e da mãe de Dora, que se implicaram na alfabetização da aluna e da filha. Tal fato favoreceu a identificação positiva de Dora com essas duas mulheres que marcaram sua trajetória na escola. Durante a entrevista, os afetos construídos nesse episódio da vida de Dora ressurgiram nas entrelinhas, principalmente quando ela se referia à sua relação com os alunos e as alunas da escola; o olhar generoso, a preocupação com o ser humano existente por detrás da farda escolar, o esforço no acolhimento necessário ao aluno difícil foram elementos que teimavam em aparecer entre as falas de Dora.

Nesse sentido, o encontro, as interações sociais, também podem possibilitar aprendizagens significativas no âmbito dos processos de se tornar professor, em que a experiência constitui-se em refúgio dos diversos saberes construídos por esses sujeitos sociais em suas trajetórias.

Já os processos de socialização secundária ocorrem no campo das instituições, são espaços mais delimitados em que a realidade interiorizada pelos sujeitos não se apresenta como única possível, mas como realidade parcial inerente a um determinado campo institucional, seja a escola, a universidade etc. Desse modo, a socialização secundária é menos dependente de componentes afetivos do que a socialização primária. A percepção de alunos, sobre a função do professor, por exemplo, remete ao fato de que eles reconhecem o professor como um profissional, em uma instituição, com determinadas características que, uma vez generalizadas, representam a docência. Ora, a identificação ocorre muito mais no plano da eficiência na execução de uma determinada tarefa na sociedade do que no campo das relações afetivas, ou seja, o fato de que alguns alunos avaliem como maravilhosas as aulas de um professor é o que possibilita a identificação com ele, pois:

A socialização secundária é a interiorização de "submundos" institucionais ou baseados em instituições. A 
extensão e caráter destes são, portanto determinados pela complexidade da divisão do trabalho e a concomitante distribuição social do conhecimento. [...] Os "submundos" interiorizados na socialização secundária são geralmente realidades parciais, em contraste com o "mundo básico" adquirido na socialização primária. Contudo, eles também são realidades mais ou menos coerentes, caracterizadas por componentes normativos e afetivos assim como cognoscitivos (Berger; Luckmann, 2005, p. 184).

Assim, não se consideram tais aspectos como comportamentos individuais desconectados da sociedade na qual os sujeitos estão inseridos. É necessário compreender a relação dialética que se estabelece entre os mecanismos de subjetivação e de objetivação que se dão no contexto das interações sociais. Dito de outra maneira, a forma como as professoras interpretam situações objetivas remetem ao modo como elas interiorizam tal realidade e como se situam no mundo. Ao mesmo tempo, diz respeito não só a um aspecto singular, mas representa as condições de vários outros sujeitos sociais que pertencem a contextos semelhantes ao de Clara, Dora, Ana etc., ou seja, há condições em que a dependência feminina em relação às escolhas e projetos de vida se coloca, quase sempre, nas mãos de outros, seja o marido, o irmão, o pai ou mesmo a mãe. Revela-se a própria condição feminina, em uma sociedade em que os papéis de mulher, mãe e cuidadora estão historicamente relacionados à docência.

\section{As Experiências com o Teatro: saber da experiência e trabalho docente}

Percebe-se, nos depoimentos das professoras, que os contatos iniciais que elas tiveram com o teatro nem sempre ocorreram de forma harmoniosa ou mesmo prazerosa. Alguns relatos revelam, inclusive, situações traumáticas vivenciadas na escola, conforme se vê no relato de Dora:

Meu primeiro contato com o teatro foi horrível [...] como eu falei anteriormente eu era aquela criança muito calada [...] eu ficava assim num cantinho, aquela aluna que sentava na primeira fila, mas só respirava [...] eu era assim, Deus me livre, muito matuta mesmo, tímida mesmo [...] e aí como eu estudava em colégio de freiras [...] sempre essas datas 
comemorativas os alunos, tinham que representar alguma coisa pra mãe, pro pai, pro professor [...] e aí a primeira experiência, foi uma peça do dia das mães que eu tive que representar [...] foi assim [...] acho que se eu levasse uma pancada tinha doído menos [...] eu não gostava de fazer, eu não me via fazendo aquilo, e eu não tinha que falar [...] sei lá, eu só tinha que ficar lá na frente [...] aí eu passei muitos anos assim indignada [...] eu cresci assim pensando, eu não suporto teatro, eu não gosto, não é a minha praia [...] (Dora) (Grifos meus).

Observa-se, no depoimento acima, a utilização de representações teatrais em datas comemorativas: era o famoso teatrinho na escola, discutido por Gil (2004), com forte tradição religiosa. $O$ teatro era utilizado como elemento festivo em datas específicas na escola. Tal fato remete ao período em que a presença da educação artística produzia práticas, com as mais diversas formas artísticas, numa perspectiva superficial e utilitária. Por outro lado, trata-se de uma experiência que marcou a vida de Dora durante muitos anos; e que desencadeou um processo de indignação que, longe de provocar a estagnação na situação-problema, possibilitou a superação da dificuldade vivenciada, superando a situação da época em que, provavelmente, a voz de Dora não foi considerada. Observa-se, no depoimento a seguir, de que modo ela, anos depois, revive a experiência de outra forma, transformando-a em saber, praticado em seu trabalho, com os alunos na sala de aula:

[...] e aí passaram-se os anos e eu cheguei à Universidade [...] No magistério eu sempre me esquivava, sempre tem aquela história, tem o grupo da dança, tem o grupo [...] eu sempre ficava com aquele que não precisasse ir lá pra frente, mas na Universidade não tem como, ou você vai ou você dança, literalmente, e aí nós tivemos que fazer uma apresentação, um teatro na Universidade, uma paródia [...] aquele teatro estava lotado, o grupo que eu peguei era mais devagar do que eu, [...] e aí eu tive que tomar a frente, tive que planejar a coreografia a outra colega fez a produção da letra da paródia e aí ninguém sabia o que fazer como representar [...] a gente tinha uma semana e era a nota do mês e para acabar de completar resolvemos colocar as menores atrás e as maiores na frente [...] como eu era uma das maiores, eu fui pra frente e aí eu pensei, na hora eu vou travar [...] mas não tem aquela história, a ocasião faz o ladrão, então a necessidade faz você [...] e aí nós fomos 
fazer essa apresentação [...] eu me diverti muito [...] foi muito gostosa essa apresentação, olhar o teatro [...] e aí tinha uma colega que disse: Dora, a gente não olha pra ninguém, olha por cima, você se perde você olha por cima, e assim eu fiz, deu certo (Dora) (Grifos meus).

A concepção de teatro apontada por Dora apresenta elementos que traduzem tanto a dança como o teatro. $\mathrm{O}$ vocábulo coreografia e a menção do teatro como espaço físico associado ao teatro como apresentação de um espetáculo constituído por um texto, no caso adaptado para a encenação, a paródia, revelam a pouca distinção que Dora faz entre o teatro/espaço físico e o teatro/espetáculo. Em outras palavras, em sua concepção o teatro acontece inexoravelmente no teatro (espaço físico).

Assim, a partir de uma situação imposta institucionalmente, Dora se vê diante de um grande desafio: a exposição do próprio corpo diante de um público. $\mathrm{O}$ evento narrado apresenta também o que Dora considera como teatro, realizado não na escola, mas na universidade (as professoras participantes desta pesquisa são funcionárias da rede pública de ensino do estado do Acre e nenhuma possui formação específica na área de Artes). O teatro é utilizado na universidade como instrumento de avaliação. Nesse sentido, a didatização dessa forma artística é reduzida a uma atividade em que as alunas/professoras tateiam às cegas os caminhos percorridos para a realização dessa tarefa, que é avaliada quantitativamente naquele espaço acadêmico. Mesmo assim, a experiência de Dora na universidade é agregada à sua trajetória e transformada significativamente na sala de aula com seus alunos, conforme o seguinte depoimento:

Hoje trabalho com adolescente, com essa experiência da minha infância, essa da universidade [...] aprendi a nunca obrigar o aluno numa aula de teatro ou dramatização, não obrigá-lo a representar, porque, você pode criar um trauma pro resto da vida dele, porque você tem que conhecer os tímidos, você tem que se enxergar naquele aluno $\mathrm{e}$ aproveitar aqueles que são mais saídos, mais desapegados das coisas, sem deixar de chamar o outro, mas na medida dele, na possibilidade dele, na medida em que ele vai se desenvolvendo [...] Eu aprendi essas coisas assim, aprendi 
a observar muito os meus alunos, então agora mesmo eu trabalhei com eles, trabalhei e estou trabalhando ainda teatro (Grifos meus).

Destaca-se, nesse depoimento, o fato de que Dora foi efetivamente marcada pela experiência. Larrosa (2004) afirma que o saber da experiência é construído a partir daquilo que nos toca, e não de informações. $\mathrm{O}$ autor distingue a experiência da informação e diz que vivemos numa sociedade de informação, onde o que importa é a quantidade de informações obtidas. No entanto, nem toda informação adquirida se configura como experiência, na medida em que a experiência exige do sujeito que a vivencia uma disponibilidade para ser tocado e atravessado por ela. Larrosa também afirma que a condição para tal estado de disponibilidade se dá pelo exercício de interrupção de práticas cotidianas repletas de velocidade, de um movimento desenfreado em fazer coisas, pois, segundo o autor, "[...] não somos apenas sujeitos ultrainformados, transbordantes de opiniões e superestimulados, mas também sujeitos cheios de vontade e hiperativos" (Larrosa, 2004, p. 159):

A experiência, a possibilidade de que algo nos passe ou nos aconteça ou nos toque, requer um gesto de interrupção, um gesto que é quase impossível nos tempos que correm: requer parar para pensar, para olhar, parar para escutar, pensar mais devagar, olhar mais devagar e escutar mais devagar; parar para sentir, sentir mais devagar, demorar-se nos detalhes, suspender a opinião, suspender o juízo, suspender a vontade, suspender o automatismo da ação, cultivar a atenção e a delicadeza, abrir os olhos e os ouvidos, falar sobre o que nos acontece, aprender a lentidão, escutar os outros, cultivar a arte do encontro, calar muito, ter paciência e dar-se tempo e espaço (Larrosa, 2004, p. 160).

Sendo assim, a experiência com o fazer teatral realizada por Dora se configurou como elemento significativo para sua trajetória docente. A representação social do teatro, como atividade envolvendo quem faz e quem assiste, se revela em sua narrativa. Infere-se que Dora percebe o fazer teatral como espetacular, compreendido aqui na perspectiva etnocenológica, ou seja, a partir de movimentos, gestos, entonações vocais e 
intenções que fogem ao cotidiano, se apresentando na dimensão da "[...] espetacularidade (quando o sujeito toma consciência clara, reflexiva, do olhar do outro e de seu próprio olhar alertar para apreciar a alteridade)" (Bião, 2009, p. 93, grifos do autor).

Nos depoimentos abaixo, percebe-se também a experiência com o teatro em outros tempos e espaços, que se deslocam para os espaços e tempos escolares, por meio das práticas das professoras:

[...] na minha casa a gente tinha uma vivência com a literatura muito forte [...] claro que era a literatura de cordel, aquelas histórias de Trancoso, que as pessoas antigamente gostavam [...] porque não tinha televisão, então a gente sempre estava lendo e se reunindo no final da tarde para ouvir as literaturas orais, nos vizinhos, principalmente aqueles contadores de história natos [...] $\mathrm{E}$ quando eu comecei a trabalhar na alfabetização de crianças eu comecei a introduzir o teatro para poder ensinar, a gente dramatizava historinha, a gente dramatizava a vivência também. Pro dia das mães era muito mais fácil a gente trabalhar o cotidiano da criança do que buscar na literatura escrita. Quanto ao texto, eu trabalhava muito com a literatura oral, a gente conversava em sala, sobre a vivência que a mãe tinha dentro de casa, por exemplo, no dia das mães como é que a mãe age dentro de casa, como ela faz com isso, como é que ela te chama à atenção, aí começava a pesquisar [...] (Sandra) (Grifos meus).

Em seu relato, Sandra associa a recepção de histórias orais com a sua prática do teatro na escola. Uma literatura coletiva, isto é, que não era lida apenas por um leitor isolado, mas lida no grupo, lida em voz alta e também contada para um público ouvinte. Provavelmente não só a boca se mexia, mas toda a face, o corpo inquieto, o gesto que arrematava a história, movimento tão comum aos contadores de causos, aos contadores de histórias, com suas entonações dançantes, produzindo ruídos e cores entre as palavras espalhadas pelos quatro cantos da floresta. Sandra distingue a dramatização da história da dramatização da vivência. Remete ao cotidiano traduzido em pura espetacularidade, à espetacularidade dos contadores de história da infância de Sandra e a transposição dos elementos do cotidiano dos alunos para formas extracotidianas apresentadas na escola, pois, “[...] 
por 'espetacular' deve-se entender uma forma de ser, de se comportar, de se movimentar, de agir no espaço, de se emocionar, de falar, de cantar e de se enfeitar. Uma forma distinta das ações banais do cotidiano" (Pradier, 1999, p. 24).

Os depoimentos das professoras relatam situações diferenciadas sobre o primeiro contato com o teatro e seus desdobramentos em sala de aula. Percebe-se, também, a concepção de teatro subjacente em tais depoimentos, assim como revelam a presença de outros espaços em que as professoras participaram, e ainda participam, de práticas teatrais articuladas às práticas de letramento, como no relato a seguir:

[...] eu vou relatar como teatro, porque na minha cabeça foi teatro [...]_quando eu tive o meu primeiro filho, quando ele tinha uns três anos de idade, eu o achava muito novinho, eu morava numa casa muito apertada, e no meu quarto só cabia a minha cama, a caminha dele e o guarda-roupa. E ele insistia, chorava de noite pra ir à escola. $\mathrm{E}$ a gente tinha que colocar ele dentro do carro e mostrar a escola. Pois, quando foi um dia eu disse: poxa, vou brincar com ele, e fiz uma espécie de teatro. Minha cama era a rua, de um lado da cama era a nossa casa e do outro era a escola [...] quando eu estava de um lado da cama eu arrumava ele pra ir à escola. Eu comprei todo o material para alfabetizá-lo [...] era como se ele realmente fosse pra escola, ele me dava beijinho e dizia: mamãe, vou pra escola. Aí ele rodeava a cama, ia pro outro cantinho, eu já era a professora e nessa brincadeira, quando ele chegava eu era a professora, aí eu dava bom dia, e nessa brincadeira, nesse teatro, eu chamo de teatro, eu alfabetizei meu filho. E quando eu vi que ele estava alfabetizado, até eu me admirei com aquilo [...] (Dora) (Grifos meus).

Para Dora, a experiência que vivenciou com seu filho foi compreendida numa dimensão espetacular, na medida em que ela tinha a consciência de que suas ações, gestos, falas, relação com os objetos, faziam parte de um universo diferente do cotidiano. No entanto, a ausência do espectador não caracteriza tal experiência como espetacular. Por outro lado, o engajamento de Dora no jogo proposto para lidar com os desejos do filho possibilitou que a criança aprendesse a ler. Ora, a intenção inicial não era ensinar. Assim, Dora não estava utilizando o que ela denomina de teatro para alfabetizar 
seu filho; esse processo aconteceu naturalmente, como resultado de uma generosidade de Dora em lidar com o outro, disponibilizando-se a compartilhar um encontro em que a dimensão ficcional estava presente e que funcionou como dispositivo transformador da realidade cotidiana. Se, para Dora, isso foi reconhecido como teatro, provavelmente para seu filho não o foi, pois o jogo do faz de conta infantil ou o jogo dramático é uma ação realizada pela criança como forma de compreensão da realidade, conforme Slade (1978). No entanto, embora não exista a presença do espectador, o que tradicionalmente caracteriza a arte teatral, a concepção de teatro apresentada por Dora apresenta elementos que estão no cerne de muitas discussões sobre o teatro contemporâneo, que não foram o foco deste estudo, e merecem uma investigação futura.

Outros aspectos se apresentam em alguns depoimentos analisados e se referem a um fazer teatral das professoras relacionado diretamente às práticas de grupos de teatro da cidade. Sobre esse assunto, Silva (2004) trabalha com a hipótese, em sua pesquisa, de que os grupos teatrais constituem um espaço formativo alicerçado no fazer teatral e na formação do professor diretor. Em seu trabalho, Silva também remete a espaços formativos não escolares e à formação humana. Em outro estudo recente, Belico (2006) afirma que, na formação de atores em Belo Horizonte, a arte precedeu a escola e, que possui, como elemento motivador, a figura do encenador.

$\mathrm{O}$ fazer teatral realizado por essas professoras em seus grupos de teatro reporta a reflexões no campo da formação de professores nos cursos de licenciatura em teatro, conduz à importância de se fazer teatro para ser professor de teatro. Tal discussão envolve tanto a dimensão docente quanto artística, na medida em que se considera o fazer teatral do futuro docente como fator fundamental para o engajamento em sua área de atuação. O teatro é uma arte prática e, como tal, não pode prescindir dessa perspectiva.

\section{A Produção das Preferências}

Os três modos de produção cultural, a arte erudita, a arte popular e a arte comercial, agem na formação da percepção e da apreciação dos docentes, tornando-se 
fatores importantes para a construção de suas escolhas estéticas ou, em outras palavras, na constituição de seu gosto estético. Tal discussão se torna relevante visto que esses fatores são elementos significativos que interferem, mais fortemente, nos processos de formação de professores e professoras que não possuem formação inicial em arte em Rio Branco, conforme comenta Sandra sobre sua dificuldade de acesso ao teatro devido a sua condição social:

Na minha vida assim eu não tive acesso a peças de teatro, porque eu era uma criança pobre, eu trabalhei em casa de família muito tempo, quando consegui um emprego como professora, trabalhei na zona rural, passei vários anos trabalhando na zona rural, até hoje eu não tenho tempo de assistir peças. É muito legal, eu gosto [...] (Sandra) (Grifos meus).

No que tange ao teatro, outra discussão que se impõe diz respeito ao que é teatro e o que não é teatro, e aos sistemas de legitimação social desses processos. A distinção é estabelecida no campo e a hierarquização dos tipos de teatro presentes no mercado, assim como as estruturas de percepção e apreciação desses produtos também é produzida no campo, pois:

Essa estrutura que se apresenta em todos os gêneros artísticos, e há muito tempo, tende hoje a funcionar como uma estrutura mental, organizando a produção e a percepção dos produtos: a oposição entre a arte e o dinheiro (o "comercial") é o princípio gerador da maior parte dos julgamentos que, em matéria de teatro, de cinema, de pintura, de literatura, pretendem estabelecer a fronteira entre o que é arte e o que não é, entre a arte "burguesa" e a arte "intelectual", entre a arte "tradicional" e a arte de "vanguarda" (Bourdieu, 2005, p. 187).

Nesse sentido, o teatro é considerado, pelas professoras, como pouco acessível e, portanto, distante de sua realidade social e de seus alunos:

[...] ano passado a gente pegou os alunos pra assistir $\mathrm{X}$, quinta A e quinta B, e os alunos estão sentindo falta, estão pedindo pra ir de novo [...] e tem até um grupo de teatro que tá se formando na escola, um grupo de meninos pequenininhos, mas que adoram teatro, eu tenho certeza que 
isso é fruto das peças que eles foram assistir na época, que eles gostaram, eles nunca tinham entrado no teatro antes, a maioria, na verdade, esse hábito de ir ao teatro na nossa periferia [...] a carência dos pais [...] as crianças têm muita vontade, mas eles dizem que é caro, mas por que é caro? Porque eles não têm mesmo, né [...] (Márcia) (Grifos meus).

Por meio do depoimento de Márcia evidencia-se que as condições de acesso tornaram-se o principal problema para seus alunos. A importância da formação do espectador, por meio da ida ao teatro, se coloca como fator fundamental para a construção do gosto por essa arte nos alunos. Observa-se, no depoimento dessa professora, a situação de marginalização cultural vivenciada por seus alunos, que, pelo fato de não terem acesso aos espetáculos de teatro, são usurpados de seu direto a essa arte. Nessa perspectiva, o acesso a essa forma artística é tido como privilégio e não como direito, fenômeno inaceitável numa sociedade democrática (Cândido, 1995).

\section{Considerações Finais}

Nem todas as experiências com o teatro, realizadas num espaço escolar, podem se configurar como ideais ou significativas para professores, professoras, alunos e alunas neste país. No entanto, não se pode perder de vista que, em muitos casos, essas experiências serão as únicas oportunidades de acesso ao teatro para crianças e jovens das classes populares. Tais experiências, que se caracterizam como processos de socialização secundária, podem não se constituir em processos tão marcantes quanto os de socialização primária, ocorridos na infância. Todavia, estão longe de poderem ser anulados como elementos impactantes nas trajetórias formativas de vários profissionais.

Assim, um dos aspectos significativos em relação ao quantitativo de docentes selecionados para a realização das entrevistas foi, sem dúvida, o fato de todos os docentes serem mulheres. Esse fato foi problematizado, procurando-se compreender as representações sociais da figura feminina no campo da profissão docente, considerando os aspectos subjetivos das professoras, em relação às configurações sociais que possibilitaram a constituição das identificações com a profissão docente. 
Não se tratou de uma expedição em busca das identidades dessas docentes, de se tecer diagnósticos sobre a competência de professoras para lidar com a arte, com o teatro na escola, mas, sim, tratou-se dos atravessamentos que afetaram suas trajetórias formativas e suas histórias de vida e saber. Os processos de socialização foram discutidos e, sem dúvida, trouxeram contribuições significativas para a compreensão da constituição das preferências das professoras e dos aspectos que marcaram e marcam suas trajetórias como profissionais da educação. Todavia, existem aspectos que ainda estão longe de serem aquietados, tais como: a discussão em torno das habilidades inatas dos indivíduos, o que dá margem, principalmente no campo artístico, a diversas concepções sobre o talento e o dom. Dito de outra maneira, concepções sobre o que se pode aprender e o que é inato. Não se pretendeu aqui esgotar esse assunto nem, tampouco, encerrar a discussão; ao contrário, tal aspecto merece ainda ser amplamente investigado. De forma a que, quem sabe, e com o benefício do tempo, possam a ciência e a arte descortinar de vez esse véu de Ísis. Acredita-se que este lugar ainda não esteja suficientemente explorado; entre a capacidade de o sujeito aprender teatro e a possibilidade de ter ou não o talento. No entanto, tal aspecto, isto é, a idéia de que já se nasce artista e com talento, não deve ser considerado como critério para justificar a pouca importância da arte na escola ou mesmo da aprendizagem e do aperfeiçoamento de atrizes e atores em escolas livres ou universidades. Mesmo aqueles que consideram a presença do talento como dispositivo de qualificação do desempenho artístico não descartam a importância do trabalho de formação do ator, que se traduz em aprendizagem. Esse fenômeno, para o Acre, é particularmente importante, na medida em que a história da emergência das atividades teatrais nessa região traz consigo uma tradição pautada no espontaneísmo do aprender-fazendo, exclusivamente, sem espaços institucionais de aprendizagem dessa arte, seja a escola, a universidade, ou mesmo as escolas livres. Tal fenômeno necessita de uma investigação mais aprofundada, para que a distância entre os discursos construídos nesses 
espaços, ou seja, nos espaços dos fazedores de teatro, e os construídos nas escolas e universidades seja encurtada.

\section{Referências}

BELICO, Dayse Lúcia Soares. A Formação de Atores em Belo Horizonte: saberes em movimento. 2006. Dissertação (Mestrado em Educação) - Programa de Pós-Graduação em Educação Conhecimento e Inclusão Social, Universidade Federal de Minas Gerais, Belo Horizonte, 2006.

BERGER, Peter Ludwig; LUCKMANN, Thomas. A Construção Social da Realidade. 25. ed. Petrópolis: Vozes, 2005.

BIÃO, Armindo. Etnocenologia e a Cena Baiana: textos resumidos. Salvador: P\&A, 2009.

BOURDIEU, Pierre. Gostos de Classe e Estilos de Vida. In: ORTIZ, Renato (Org.). Pierre Bourdieu: sociologia. São Paulo: Ática, 1983. P. 83-121.

BOURDIEU, Pierre. As Regras da Arte: gênese e estrutura do campo literário. 2. ed. São Paulo: Companhia das Letras, 2005.

CÂNDIDO, Antônio. Vários Escritos. São Paulo: Duas Cidades, 1995.

GIL, João Pedro Alcântara. Implicações Metodológicas da Teoria Crítica na Pesquisa com Teatro e Educação. In: CORRÊA, Ayrton Dutra (Org.). Ensino de Artes: múltiplos olhares. Ijuí: Unijuí, 2004. P. 175-193.

LAHIRE, Bernard. Sucesso Escolar nos Meios Populares: as razões do improvável. São Paulo: Ática, 2008.

LARROSA, Jorge. Sobre a Lição. In: LARROSA, Jorge. Pedagogia Profana. 4. ed. Belo Horizonte: Autêntica, 2006. P. 139-146.

LARROSA, Jorge. Experiência e Paixão. In: LARROSA, Jorge. Linguagem e Educação Depois de Babel. Belo Horizonte: Autêntica, 2004. P. 151-165.

NUNES, Clarice. A Sina Desvendada. Educação em Revista, Belo Horizonte, v. 2, p. 58-65, dez. 1985.

PRADIER, Jean-Marie. Etnocenologia: textos selecionados. In: GREINER, Christine; BIÃO, Armindo (Org.) Etnocenologia. São Paulo: Annablume, 1999. P. 23-29.

SILVA, Mário Luiz Rosa da. Grupos Teatrais Estudantis: possibilidades educativas e valorização das dimensões artísticas em propostas e experiências do teatro iniciado na escola. 2004. Dissertação (Mestrado em Educação) - Programa de Pós-Graduação em Educação Conhecimento e Inclusão Social, Universidade Federal de Minas Gerais, Belo Horizonte, 2004.

SLADE, Peter. O Jogo Dramático Infantil. São Paulo: Summus, 1978. 
Andréa Maria Favilla Lobo é atriz e pesquisadora. Professora Adjunta do Curso de Licenciatura em Artes Cênicas: teatro do Centro de Educação Letras e Artes - CELA da Universidade Federal do Acre - UFAC.

E-mail: lobo.andrea@gmail.com

Recebido em janeiro de 2011

Aprovado em março de 2011 